\title{
BARKOD DNA PADA TANAMAN GAMBIR (Uncaria gambir (Hunter) Roxb.) BERDASARKAN GEN matK DAN rbcL
}

\author{
Epi Supri Wardi ${ }^{1}$, Jamsari Jamsari ${ }^{2}$, Irwandi ${ }^{1}$, Diza Sartika ${ }^{1}$, Azma Risilvia Ningsih ${ }^{1}$ \\ ${ }^{1}$ Sekolah Tinggi Farmasi Indonesia Yayasan Perintis Padang \\ ${ }^{2}$ Fakultas Pertanian, Universitas Andalas \\ Email : epi.supriwardi@gmail.com
}

\begin{abstract}
Gambir (Uncaria gambir (Hunter) Roxb.) is a superior commodity of West Sumatra that has many benefits and has been used as a drug. Plant identification carried out morphologically has many weaknesses, with the development of electronic and genetic technology now a new method of species identification has been developed. plants and animals, namely DNA barcoding technology that uses standard short pieces of DNA Species identification methods have been agreed to using standard DNA barcodes are rbcL genes and matK genes. The purpose of this study is to find out DNA Barkoding candidates between matK and rbcL which can identify gambier (Uncaria gambir (Hunter) Roxb.) Which is good. Polymerase Chain Reaction (PCR) technique is used to amplify rbcL and matK gene sequences through universal primers. The DNA sequences of the MATC sequence in the GR sample (Riau Gambir) produced a similarity rate of $98.79 \%$ with Nauclea diderrichii, for the rbcL sequence GC (Cubadak Gambir) samples produced a similarity rate of $99.81 \%$ with Uncaria macrophylla, and GR (Gambir Riau) samples produced the similarity rate was $96.84 \%$ with Uncaria macrophylla based on analysis with BOLD Systems. This similarity indicates the low variation in intraspecific genetics for the identification or confirmation of gambir species.
\end{abstract}

Key words: DNA barcode, rbcL, matK, Uncaria gambir.

\section{PENDAHULUAN}

Tanaman gambir, Uncaria gambir

(Hunter) Roxb. merupakan komoditas unggulan Provinsi Sumatera Barat, sebagai komoditas ekspor yang memberikan sumbangan besar terhadap Produk Domestik Regional Bruto (PDRB) daerah yang pada gilirannya akan meningkatkan devisa Negara. ${ }^{1}$ Penelitian tentang khasiat dan pemanfaatan gambir sebagai tanaman obat telah banyak dilakukan terutama kandungan katekin pada gambir yang terbukti dapat berfungsi sebagai antihiperkolesterolemia pada mencit putih jantan (Mus muculus) ${ }^{2}$, sebagai antioksidan dan juga antibakteri. ${ }^{3}$

Sekarang gambir telah banyak diproduksi menjadi beberapa bentuk sediaan obat herbal karena manfaat dan kegunaannya yang bervariasi.Salah satu manfaat dari gambir adalah sebagai antibakteri, karena itu gambir diproduksi sebagai obat kumur. ${ }^{3}$ Identifikasi spesies tumbuhan awalnya menggunakan metode morfologi yang diidentifikasi dari bentuk fisiknya (bunga, daun, batang, cabang dan biji). ${ }^{4}$ Tumbuhan memiliki banyak keanekaragaman dan ciri fisik yang sama menyebabkan identifikasi morfologi tumbuhan kurang spesifik untuk menentukan spesies tumbuhan tertentu, identifikasi hanya bisa diterapkan untuk tanaman dewasa, memerlukan waktu lama karena pengambilan sampel harus menunggu waktu berbunga/berbuah. Selain itu pengamatan morfologi membutuhkan seorang pakar taksonomi yang ahli. ${ }^{5}$ Identifikasi morfologi hanya bisa dilakukan terhadap tanaman utuh, jika tanaman tersebut sudah dalam bentuk ekstrak atau sediaan tertentu tidak dapat lagi 
Barkod Dna Pada Tanaman Gambir (Uncaria gambir (Hunter) Roxb.) Berdasarkan Gen matK dan $r b c L$

diidentifikasi secara morfologinya. Namun, dengan adanya perkembangan teknologi elektronika dan genetika saat ini telah dikembangkan suatu metode terbaru dalam identifikasi spesies tumbuhan dan hewan, yaitu teknologi Barkod DNA yang menggunakan potongan DNA pendek standar. ${ }^{6}$

Untuk identifikasi tanaman dalam teknologi Barkod DNA disepakati menggunakan gen pengkode standar yaitu gen ribulosa-1s,5-bifosfat karboksilase ( $r b c L$ ) dan gen maturaseK (matK) yang terdapat pada kloroplas. ${ }^{7}$ Gen matK lebih banyak digunakan dalam berbagai penelitian dibandingkan gen rbcL, karena tingkat keakuratannya yang lebih spesifik pada tingkat spesies. Gen matK dijadikan gen pengkode standar untuk barkod DNA sejak tahun 2003 dan telah diuji melalui beberapa penelitian. Gen maturaseK (matK) diidentifikasi pertama kali oleh dari tanaman tembakau (Nicotiana tabacum). Gen matK merupakan gen pengkode enzim maturase bagian sub-unit $\mathrm{K}$ yang terdapat dalam kloroplas pada tanaman. ${ }^{8}$ Gen rbcL merupakan gen kloroplas yang paling banyak digunakan dalam analisis hubungan kekerabatan. ${ }^{9}$

Dua buah marker, yaitu rbcL dan matK adalah 2 dari beberapa jenis marker yang direkomendasikan oleh The Consortium for the Barcode of Life (CBOL) untuk Barkod DNA tanaman. ${ }^{10}$ Berdasarkan penelusuran singkat dalam BOLD system yang terhubung dengan database sekuens dari beberapa negara, banyak spesies belum tersedia untuk kedua DNA Barkod tersebut, termasuk untuk tanaman gambir.

Berdasarkan hal tersebut peneliti tertarik untuk melakukan penelitian terhadap tumbuhan gambir menggunakan Barkod DNA dengan gen matK dan rbcL sebagai data inventaris identitas molekuler tanaman Gambir dari Sumatera Barat.

\section{METODOLOGI PENELITIAN}

\section{Pengambilan Sampel}

Pengambilan 2 sampel daun gambir (Gambir Cubadak, Gambir Riau) di Kelurahan Maek, Kecamatan Bukik Barisan, Kabupaten Lima Puluh Kota, Provinsi Sumatera Barat.

\section{Isolasi Sampel}

Isolasi DNA menggunakan KIT GeneJet Plant Genomic DNA Purification Mini Kit. Sesuai dengan protokol KIT GeneJet Plant Genomic DNA Purification Mini Kit sampel ditimbang $100 \mathrm{mg}$ diperkecil ukuran partikelnya dengan menggunakan gunting dan ditambahkan dengan nitrogrn cair, gerus sampai halus masukkan ke dalam mikrotube ditambahkan dengan $350 \mu \mathrm{L}$ Lysis Bufer A, vortex selama 10 sampai 20 detik. Ditambahkan Lysis Buffer B $50 \mu \mathrm{L}$ dan RNAse $20 \mu \mathrm{L}$, vortex selama 1 menit. Inkubasi selama 10 menit pada suhu $65^{\circ} \mathrm{C}$, dan tambahkan 130 $\mu \mathrm{L}$ Precipitation Solution aduk 2 sampai 3 kali, inkubasi selama 5 menit di dalam es. Sentrifugasi pada kecepatan $14.000 \mathrm{rpm}$ selama 5 menit sehingga diperoleh supernatan dan pellet. Pindahkan supernatan ke dalam mikrotube baru, tambahkan $400 \mu \mathrm{L}$ Plant gDNA Binding Solution dan $400 \mu \mathrm{L}$ etanol $96 \%$ dingin, campurkan dengan membolak balik tabung 3 sampai 5 kali, ambil larutan $600 \mu \mathrm{L}$ sampai $700 \mu \mathrm{L}$ pindahkan ke dalam spin kolom, sentrifugasi pada kecepatan 8.000 rpm selama 1 menit, buang supernatant dan tambahkan $500 \mu \mathrm{L}$ Wash Bufer I, sentrifugasi pada kecepatan 10.000 rpm selama 1 menit. Buang supernatan, tambahkan $500 \mu \mathrm{L}$ Wash buffer II sentrifugasi dengan kecepatan $14.000 \mathrm{rpm}$ selama 3 menit. Buang larutannya, ganti tabung spin kolom tambahkan $100 \mu \mathrm{L}$ Elution 
Barkod Dna Pada Tanaman Gambir (Uncaria gambir (Hunter) Roxb.) Berdasarkan Gen matK dan rbcL

buffer, inkubasi 5 menit pada suhu ruangan, dan sentrifugasi pada kecepatan $10.00 \mathrm{rpm}$ selama 1 menit, hasil sentrifugasi simpan pada suhu $-20^{\circ} \mathrm{C}$.

\section{PCR dan Elektroforesis}

Pengaturan suhu thermocycler untuk primer rbcL dimulai dengan denaturasi awal pada $95^{\circ} \mathrm{C}$ selama 2 menit kemudian dilanjutkan 35 siklus $\left(95^{\circ} \mathrm{C} 30\right.$ detik, 55ㅇ 30 detik dan $72^{\circ} \mathrm{C} 1$ menit). Untuk primer matK dimulai dengan denaturasi awal pada $95^{\circ} \mathrm{C}$ selama 2 menit, kemudian dilanjutkan 35 siklus $\left(95^{\circ} \mathrm{C} 30\right.$ detik, $55^{\circ} \mathrm{C} 30$ detik, dan $72^{\circ} \mathrm{C} 1$ menit). Dilanjutkan dengan elektroforesis selama 30 menit dengan voltase 100 volt menggunakan Agarose 0,8\%. ${ }^{11}$

\section{Sekuensing dan Analysis Barkod DNA}

Sekuensing dilakukan dengan mengirim sampel hasil PCR ke Firstbase Singapura dan Analysis Barkod DNA dilakukan dengan analisa menggunakan Bold System.

\section{HASIL DAN PEMBAHASAN}

Hasil isolasi DNA berupa laruan jernih tidak berwarna (bening), dan menghasilkan produk PCR pada rentang 500-750 bp untuk primer rbcL dan 750-1000 bp untuk primer matK.

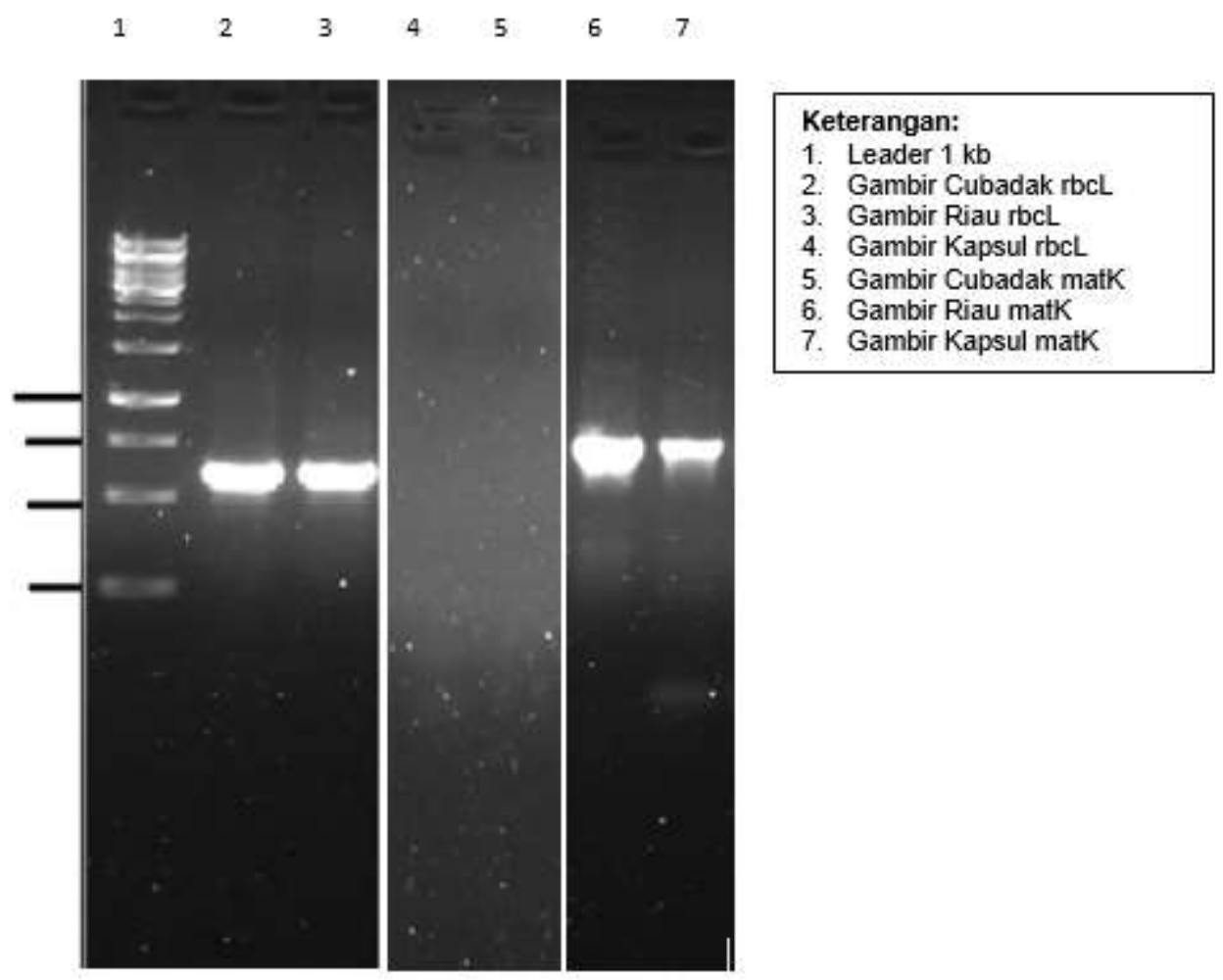

Gambar 1. Hasil elektroforesis tanaman gambir dan kapsul gambir

Kromatogram hasil sekuensing menunjukkan hasil yang berkualitas tinggi, dimana puncak yang dihasilkan jelas dan tidak saling tumpang tindih anatara puncak yang satu dengan yang lainnya baik untuk gen matK dan gen rbcL. Nilai \%HQ kromatogram yang terbaca Geneious v5.6.7 menunjukkan nilai
86.6\% untuk gen rbcL sampel Gambir Cubadak, untuk gen rbcL sampel Gambir Riau menunjukkan nilai \%HQ 77,6\% dan untuk gen matK sampel Gambir Riau menunjukkan nilai $\%$ HQ 96,1\%, sedangkan untuk sampel Gambir Kapsul menunjukkan nilai \%HQ 94,3\%. Bentuk kromatogram dari masing-masing sampel 
Barkod Dna Pada Tanaman Gambir (Uncaria gambir (Hunter) Roxb.) Berdasarkan Gen matK dan rbcL

dapat dilihat pada gambar 2-5, yang memperlihatkan puncak-puncak yang runcing dan saling terpisah, menunjukkan hasil sekuensing memilki kualitas yang baik. Nilai $\mathrm{HQ}$ merupakan nilai yang menggambarkan tentang kualitas dari puncak kromatogram hasil
sekuensing.Dimana semakin tinggi nilai $\mathrm{HQ}$ suatu kromatogram maka semakin bagus pula bentuk pucak kromatogram tersebut. ${ }^{10}$ Angka yang tertera pada puncak-puncak kromatogram tersebut menunjukkan panjang dari basa nukleotida DNA yang didapatkan.

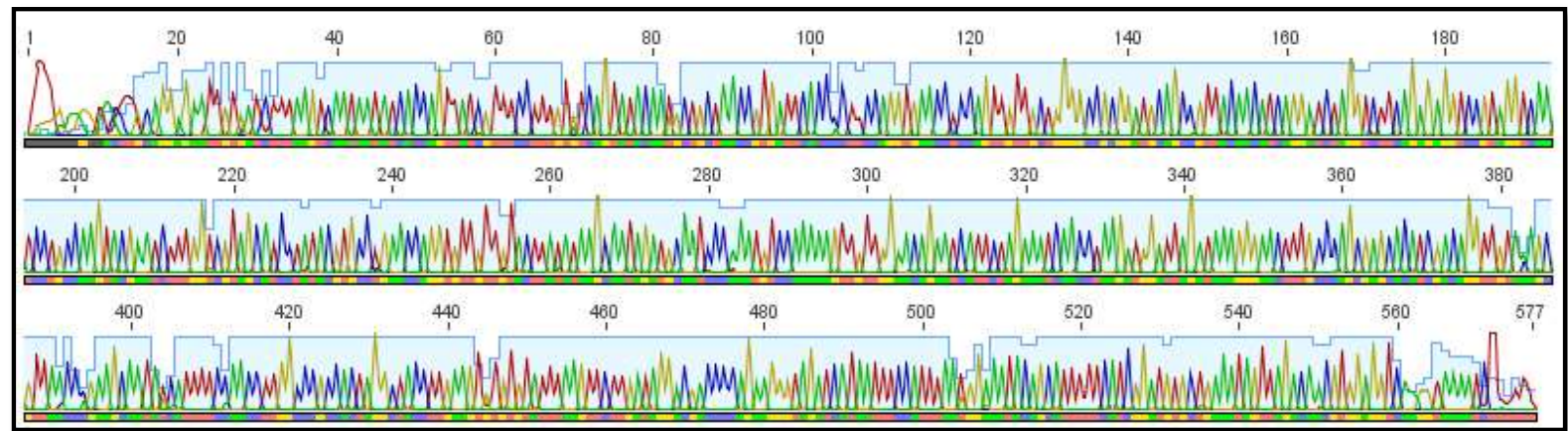

Gambar 2. Kromatogram sekuensing gen rbcL sampel gambir cubadak

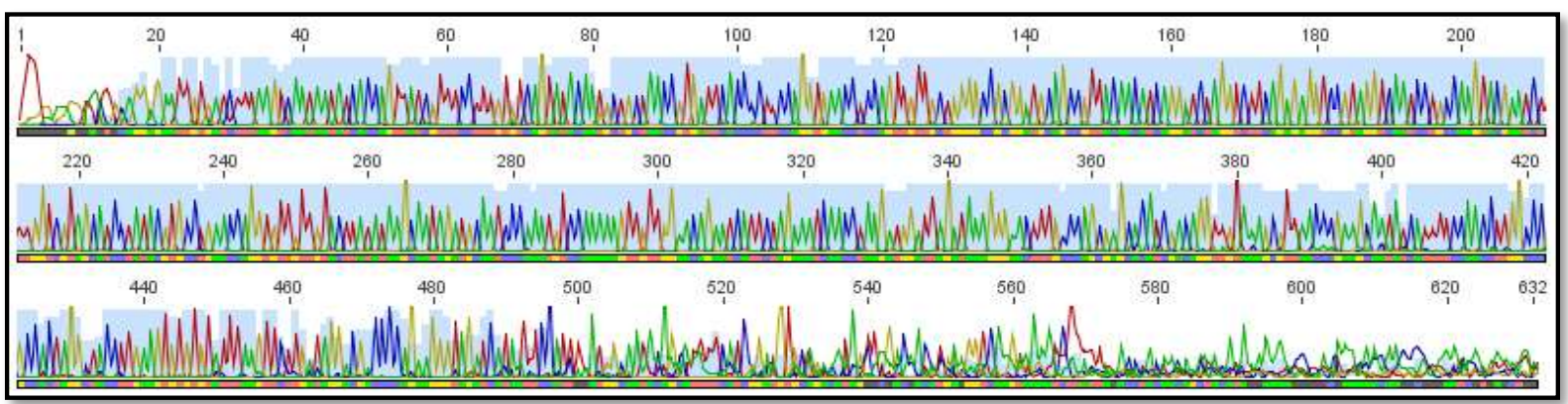

Gambar 3. Kromatogram sekuensing gen rbcL sampel Gambir Riau

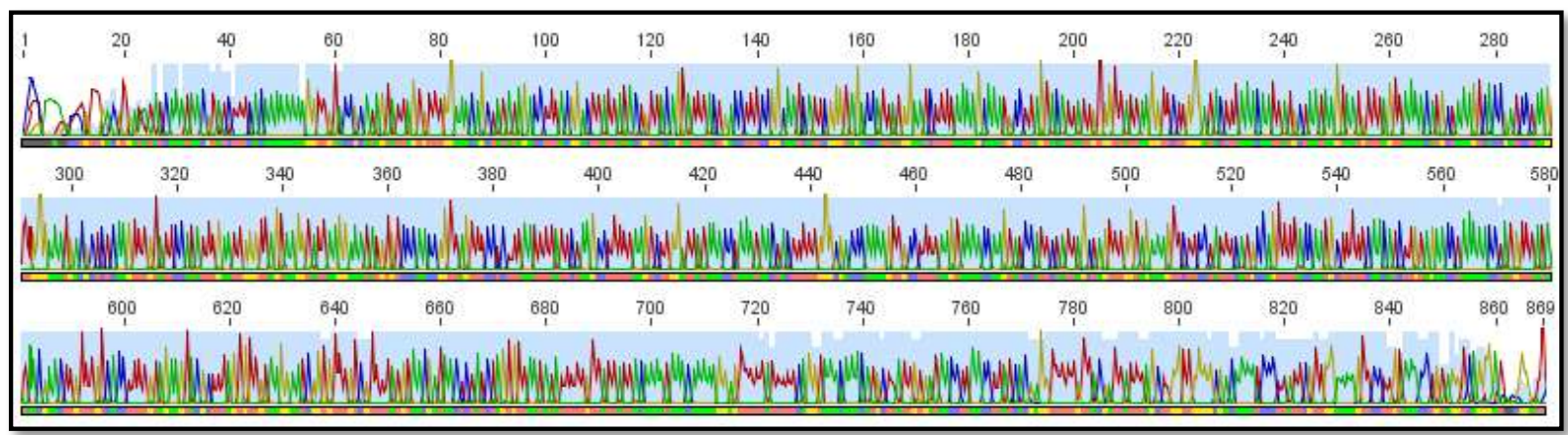

Gambar 4. Kromatogram sekuensing gen matK sampel Gambir Riau

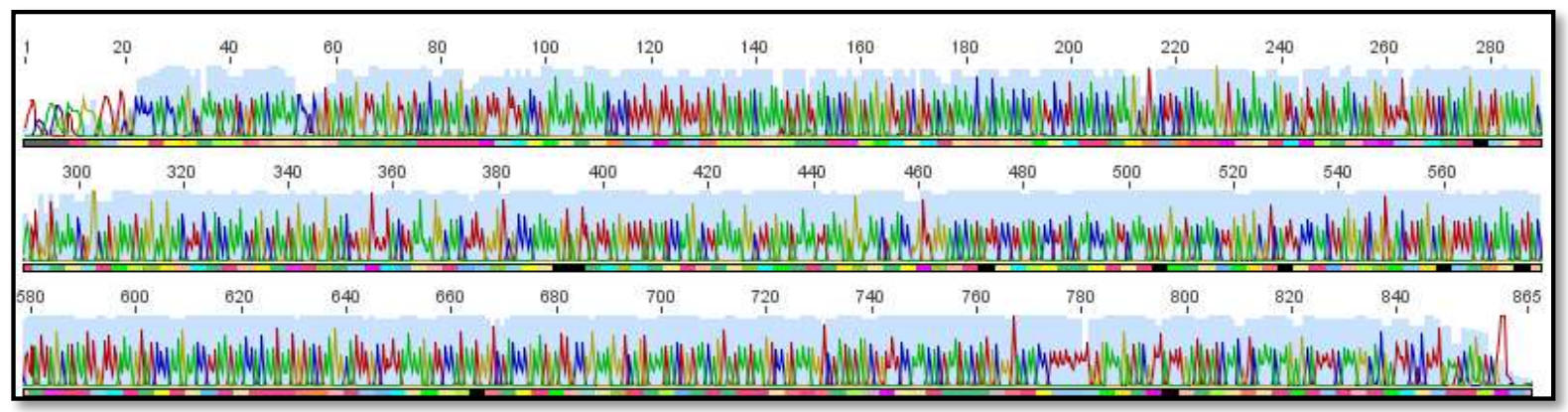

Gambar 5. Kromatogram sekuensing gen matK sampel Gambir Kapsul 

rbcL

Untuk sekuens rbcL sampel Gambir Cubadak memiliki 530 bp sekuens (gambar 5), sampel Gambir Riau memiliki 559 bp sekuens rbcL (gambar 6), untuk sekuens matK sampel
Gambir Riau memiliki 829 bp sekuens (gambar 7), untuk sekuens matK sampel Gambir Kapsul memiliki 829 bp sekuens (gambar 8).

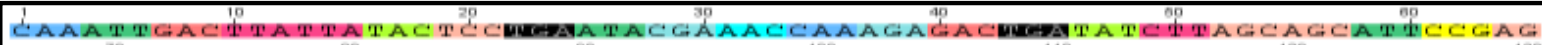

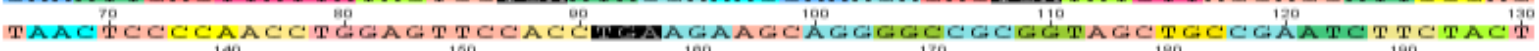

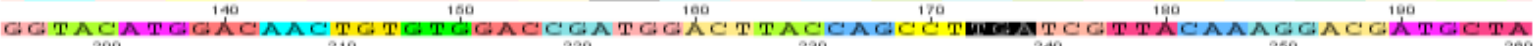
CCATATCGAGCOAGTTCOTGGAGAXGAAGATCAATATATTGCTTATGTAGCTTACOCTTTAGACD

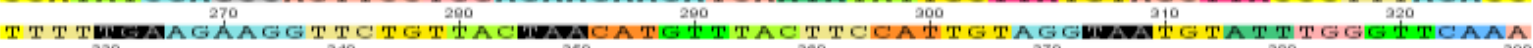

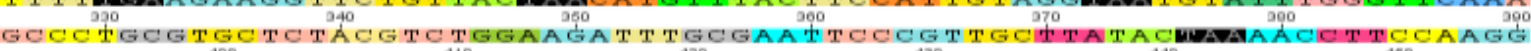
CCCGCCTCA

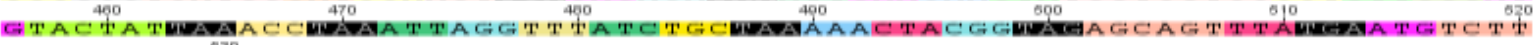
CGAGGTGGA

Gambar 6. Sekuens sampel Gambir Cubadak rbcL

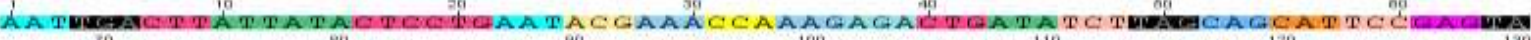
Wow

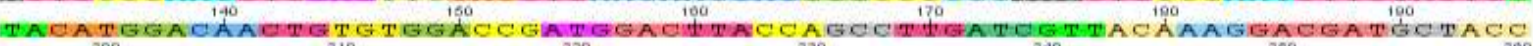

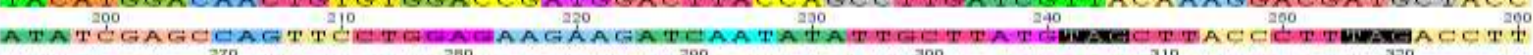

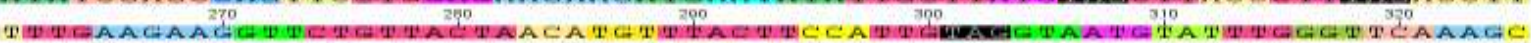
с

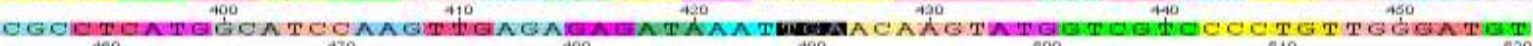

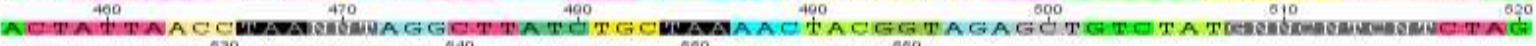

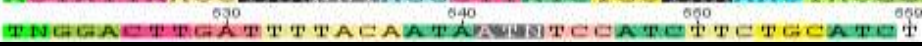

Gambar 7. Sekuens sampel Gambir Riau rbcL

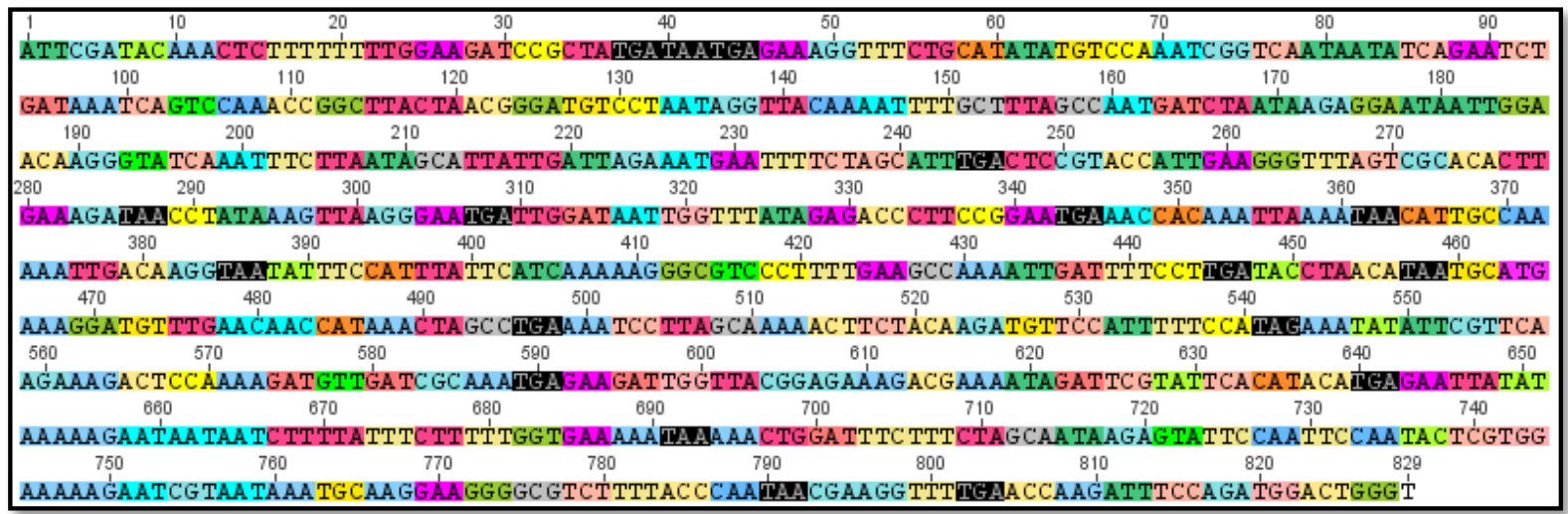

Gambar 8. Sekuens sampel Gambir Riau matK

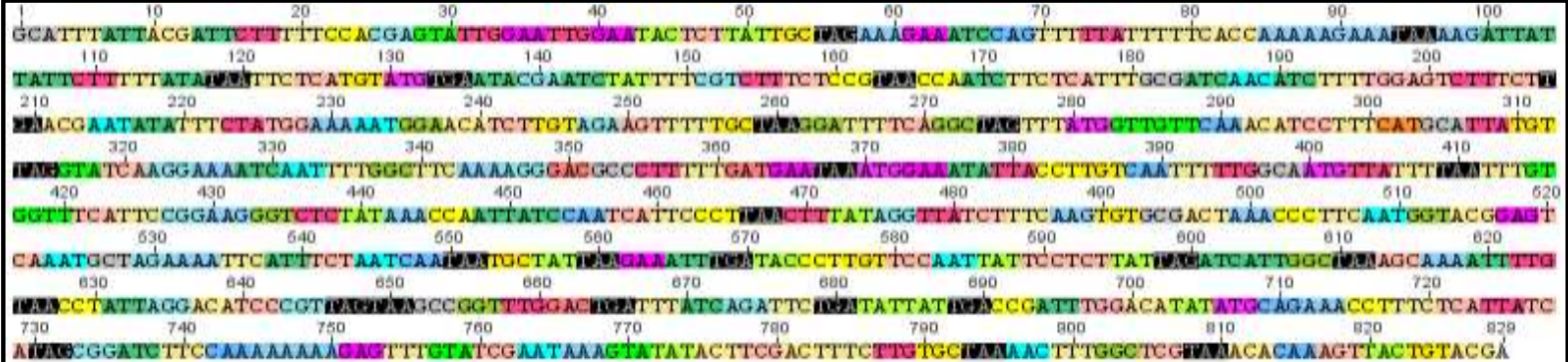

Gambar 9. Sekuens sampel Gambir Kapsul matK 
Barkod Dna Pada Tanaman Gambir (Uncaria gambir (Hunter) Roxb.) Berdasarkan Gen matK dan $r b c L$

Hasil sekuensing dianalisis dengan

Bold System sebagai softwareonline dalam penandaan DNA atau DNA Barcoding. Output dari proses ini adalah informasi lengkap mengenai spesies (data morfologi, taksonomi, dan pendukung) yang kita masukkan bila spesies yang kita input sudah terdapat datanya di sistem. ${ }^{12}$ Hasil penelusuran yang didapatkan berupa disajikan pada tabel 1 .

Tabel 1. Hasil Penelusuran Bold System

\begin{tabular}{cccc}
\hline No. & Jenis Sampel & Primer matK & Primer rbcL \\
\hline 1. & Gambir Riau & Nauclea diderrichii & Uncaria macrophylla \\
2. & Gambir Cubadak & Uncaria macrophylla & - \\
3. & Kapsul Gambir & Uncaria sp.1 MR-2013 & - \\
\hline
\end{tabular}

Gen matK lebih banyak digunakan dalam berbagai penelitian dibandingkan gen rbcLkarena gen matKdapat membedakan sampai tingkat spesies. Gen matK juga memiliki kecepatan evolusi yang tinggi dan urutan sekuens yang lebih bervariasi ${ }^{13}$, sehingga gen matKdinilai lebih baik dan lebih akurat dalam mengindentifikasi dan membedakan suatu spesies. ${ }^{10}$ Sedangkan kemampuan diskriminasi barkod rbcL lebih lemah yang telah ditunjukkanoleh beberapa publikasi sebelumnya. ${ }^{14,15}$ Walaupun kemampuan diskriminasi gen rbcL tidak lebih baik dari penanda lain, barkodrbcLmemiliki tingkat keberhasilan amplifikasi yang tinggi untuk banyak spesies dan mudahdisekuensing. ${ }^{15}$

Dari hasil perbandingan terdapat perbedaan yang nyata antara bentuk daun dan bunga dari sampel gambir dengan spesies yang terdapat pada hasil penelusuran dengan Bold System. Ini menunjukkan bahwa gen matK dan rbcL terkonservasi dan tidakmampu untuk membedakan beberapa anggota famili Rubiaceae yang berkerabat dekat.Berdasarkan hasil yang didapatkan baik gen matK maupun rbcL belum bisa mengidentifikasi tanaman dan kapsul gambir sampai pada tahap spesies.
Untuk sampel sediaan gambir Kapsul, berdasarkan hasil penelusuran dari Bold System yang terkandung dalam sediaan kapsul A adalah 99,75\% Uncaria sp. 1 MR-2013 bukan Uncaria macrophylla.

\section{KESIMPULAN}

Berdasarkan hasil dan pembahasan dapat disimpulkan bahwa sekuens barkod rbcL sampel GC (Gambir Cubadak) menghasilkan tingkat kemiripan $99,81 \%$ dengan Uncaria macrophylla, dan sampel GR (Gambir Riau) menghasilkan tingkat kemiripan 96,84\% dengan Uncaria macrophylla, sekuens barkod matK sampel GR (Gambir Riau) menghasilkan tingkat kemiripan $98,79 \%$ dengan Nauclea diderrichii dan sampel GK (Gambir Kapsul) menghasilkan tingkat kemiripan 99,75\% dengan Uncaria sp.1 MR-2013. Berdasarkan hasil penelusuran yang dilakukan baik primer matK maupun rbcL tidak ada yang dapat membedakan beberapa famili Rubiaceae, hanya dapat membedakan sampai tingkat genusnya saja.

\section{DAFTAR PUSTAKA}

1. Ariyanti PR, Aditya M. Manfaat Gambir ( Uncaria gambir Roxb ) sebagai Antioksidan. Majority. 2016;5(3):129-33.

2. Frinanda D. Efektivitas Gambir (Uncaria gambir Roxb.) sebagai Anti Hiperkolesterolemia dan Stabilisator Nilai 

$r b c L$

Darah Pada Mencit Putih (Mus musculus) Jantan. J Biol Univ Andalas (J Bio UA). 2014;3:231-7.

3. Rahmawati N, Bakhtiar A, Putra P. Isolasi Katekin dari Gambir ( Uncaria gambir ( Hunter ). Roxb ) untuk Sediaan Farmasi dan Kosmetik. J Penelit Farm Indones. 2012;1(1):6-10.

4. Kalangi C, Kamu VS, Kumaunang M. Barcode DNA Tanaman Leilem (Clerodendrum minahassae L.) Berdasarkan Gen matK. J MIPA. 2014;3(2):108.

5. Sunaryo W. Aplikasi DNA Barcoding untuk analisis keragaman genetik lai-durian (Durio zibethinus $x$ kutejensis) asal Kalimantan Timur. Pros Sem Nas Masy Biodiv Indon. 2015;1(6):1273-1277.

6. Hebert PDN, Cywinska A, Ball SL, DeWaard JR. Biological identifications through DNA barcodes. Proc R Soc B Biol Sci. 2003;270(1512):313-21.

7. Hollingsworth PM, Forrest LL, Spouge JL, Hajibabaei M, Ratnasingham S, van der Bank M, Chase MW, Cowan RS, Erickson DL, Fazekas AJ, Graham SW, James KE, Kim KJ, Kress WJ, Schneider $H$, van AlphenStahl J, Barrett SC, van den Berg C, Bogarin D, Burgess KS, Cameron KM, Carine M, Chacón J, Clark A, Clarkson JJ, Conrad F, Devey DS, Ford CS, Hedderson TA, Hollingsworth ML, Husband BC, Kelly LJ, Kesanakurti PR, Kim JS, Kim YD, Lahaye $R$, Lee $H L$, Long $D G$, Madriñán $S$, Maurin O, Meusnier I, Newmaster SG, Park CW, Percy DM, Petersen G, Richardson JE, Salazar GA, Savolainen V, Seberg O, Wilkinson MJ, Yi DK, Little DP. A DNA barcode for land plants. Proc Natl Acad Sci U S A. 2009;106(31):12794-7.

8. Soltis, Pamela, Doyle J.J. Molecular Systematics of Plants II. www.springer.com/book,1998.

9. Ohsako T, Ohnishi O. Nucleotide sequence variation of the chloroplast trnK/matK region in two wild Fagopyrum (Polygonaceae) species, F. leptopodum and F. statice. Genes Genet Syst. 2001;76(1):39-46.

10. Kolondam BJ, Lengkong E, Polii-Mandang J, Semuel R, Pinaria A. Barcode DNA Anthurium Gelombang Cinta (Anthurium plowmanii) berdasarkan gen rbcL dan matK. J Bios Logos. 2013;3(1).

11. Marmiroli N, Maestri E. Polymerase chain reaction (PCR). Food Toxicants Anal. 2007;5(6):147-87.

12. Thompson JD, Higgins DG, Gibson TJ. CLUSTAL W: Improving the sensitivity of progressive multiple sequence alignment through sequence weighting, positionspecific gap penalties and weight matrix choice. Nucleic Acids Res. 1994;22(22):4673-80.

13. Barthet MM. Expression and Function of the Chloroplast-encoded Gene matK. Phd. 2006.

14. Hollingsworth PM. Refining the DNA barcode for land plants. Proc Natl Acad Sci U S A. 2011;108(49):19451-2.

15. Hollingsworth PM, Graham SW, Little DP. Choosing and using a plant DNA barcode. PLoS One. 2011;6(5). 